Ivana Perica | Ludwig-Maximilians-Universität München, ivana.perica@|rz.uni-muenchen.de

\title{
Tertium datur
}

Lukács' Early Aesthetics and Ethics as Mirrored in Die Eigenart des Ästhetischen

\section{1. "Bei mir ist jede Sache die Fortsetzung von etwas"}

Several prominent concepts from Lukács' late Die Eigenart des Ästhetischen (1963) can already, at least embrionically, be forefelt in his early studies Soul and Form (1910/1911) and The Theory of the Novel (1915/1920). This proposition, propped up by Judith Butler's recent remark that »it is clear that many of the same problems about language, form, social totality, and transformative communication continue throughout his life ${ }^{1}{ }^{1}$ takes its lead from an assertion put forward by Michael Löwy decades ago (1976), namely that »the ideology of a given writer can be understood only in relation to his thought as a whole" and that »his thought must in turn be inserted into the world view that provides its structure of meaning «. ${ }^{2}$ These observations, the validity of which is in Lukács' case as obvious as it is commonly ignored, resound with the crucial question whether Lukács' »earlier works proved to be
Considering common compartmentalizations of Lukacs' work into the early, mature, and late phase, the article explores elements that speak to what critics regard as a scontinuity thesis،. Against possible assumptions on the prevalence of form in his early work and the dominance of the aesthetics of content in the later phases, the article explores the dialectical relationship of form and content, which comes to represent a leitmotif in Lukacs' work as a whole. Here, the early specificity of form does not consist of its domination over content but in the inability of the aesthetic to tackle the social problems of a modernity in which art and life part ways. 
fully comprehensible only in the light of the later ones $«{ }^{3}$ Before continuing in the footsteps of these suggestive remarks, let me point to one which is ingrained as a severe misapprehension of the individual stages of Lukács' intellectual and political development; a misapprehension that comes to underpin even Butler's otherwise accurate and updated Introduction. In her foreword, Butler correctly suggests that »the early emphasis on form might be said to refute the stark opposition between subjective and objective modes of experience upon which [Lukács'] later criticism relies «. ${ }^{4}$ Granted that Butler does make the pertinent remark that Lukács' »later « studies present "a change of emphasis" rather than a »self-repudiation " ${ }^{5}$ she nevertheless references to Lukács' works from around 1930 as »later criticism «. At another point, she also refers to his criticism of experimental writing as put forth in the 1950s. This seemingly unproblematic limitation of the >later Lukács to his 'politically controversial aesthetics implicitly restages an ingrained yet commonly unnoticed disregard of Lukács' late ontological and aesthetic opus magnum. Fredric Jameson also reminds that Lukács' work is commonly divided into »early Lukács «, »the later theoretician of realism ", and the »final Lukács «. ${ }^{6}$ In contrast to Butler, he does take into account the final phase, yet he also mentions that this phase is usually construed in terms of a »return to the beginning «, and that it is often implied that this return, undertaken »from a Marxist point of view «, testifies to »the failure and the vanity of the whole enterprise . $^{7}$ It goes without saying that the latter assertion, as critically referenced by Jameson, refers first and foremost to Lukács' radical years. Against assertions such as these and other possible platitudes, I demonstrate several aspects that not only endorse Jameson's thesis on Lukács' work as a "progressive exploration and enlargement of a single complex of problems $«,{ }^{8}$ but also help to illuminate the specific character of this progression and enlargement.

Taking the lead of his doctoral thesis from Thomas Metscher's estimation that Lukács' »späte Ästhetik ist, von wenigen verdienstvollen Ausnahmen [...] abgesehen, ein nicht rezipiertes Werk «, ${ }^{9}$ Daniel Göcht sets out to

3 Jameson: The Case for Georg Lukács, p. 163.

4 Butler: Introduction, p. 3.

5 Ibid.

6 Jameson: The Case for Georg Lukács, p. 163.

7 Ibid., p. 163, 162, 163.

8 Ibid.

9 Ein ungelesenes, unbekanntes Meisterwerk des 20. Jahrhunderts. Gespräch mit Thomas Metscher. In: Georg Lukács und 1968. Eine Spurensuche. Ed. Rüdiger Dannemann. Bielefeld: Aisthesis 2009, pp. 149-156, here 153. Qtd. in Göcht: Mimesis - Subjektivität - Realismus, p. 9. 
demonstrate that attentive readings of Die Eigenart des Ästhetischen may also shed a new light on the very beginnings of Lukács' aesthetic preoccupations. In support of this, I posit that an updated assessment of Die Eigenart

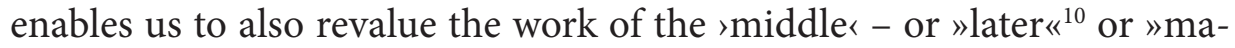
ture ${ }^{11}$ - Lukács, which often casts him as a normativistic, propagandistic, and »dogmatic ${ }^{12}$ thinker. In other words, both Lukács' early and mature aesthetics should be read as preliminaries and a prolegomenon to his final, extensive aesthetic theory that simultaneously credits art for its form-related specificity and social autonomy and acknowledges the indispensability of its content-related commentary and commitment in particular historical times and social spaces. The interest in the specificity of the aesthetic is not exclusively a concern of late Lukács, but it is doggedly consistent throughout all his creative phases - both his early and late work but arguably his politically charged writings from the late 1920s and 1930s as well. However, as militant revolutionary and, thereafter, state-socialist Soviet politics was reluctant to accept integrative approaches, ${ }^{13}$ it was not before Die Eigenart that Lukács managed to consolidate his Marxist and materialist stance on literature as a vehicle for » deeper probing of the real world ${ }^{14}{ }^{4}$ with an interest in »die philosophische Begründung der ästhetischen Setzungsart, die Ableitung der spezifischen Kategorie der Ästhetik [und] ihre Abgrenzung von anderen Gebieten.$^{15}$ In what follows, my aim in drawing on Lukács' early work is to comparatively review his late aesthetics not as an arguably resumptive liberal philosophy ${ }^{16}$ but as a theoretical completion of the raesthetics of content $<$ ( Inhaltsästhetik ) that was originally endorsed in his mature years, and for which the work from the early years serves as a preliminary phase.

My integrative assessment of Lukács' early, mature, and late aesthetics hopes to shed light on the continuity of his attempts at finding a dialectical synthesis to the age-old rift between form and content, art and life, the self and society (inner life and outside world), freedom and oppression,

10 Butler: Introduction, p. 3.

11 Arato/Breines: Young Lukács, p. 221.

12 Adorno: Reconciliation under Duress, p. 154 (Erpreßte Versöhnung, p. 255).

13 Lukács' subsequent attempts at developing a Popular Front strategy avant la lettre were stifled (cf. Rees: Introduction, pp. 32-35; Jay: Marxism and Totality, p. 103).

14 Lukács: Realism in the Balance, p. 37 (»ein tieferes Erforschen der Wirklichkeit«, Es geht um den Realismus, p. 322).

15 Lukács: Die Eigenart I, p. 7 (brackets in the original).

16 For the >liberal < traits of Lukács' aesthetics, as well as for the links he establishes between Marx and classical German aesthetics, or Marxism and bourgeois humanism, cf. Jay: Marxism and Totality, pp. 301-302. 
modernism and realism, capitalism and Bolshevism. ${ }^{17}$ Yet these consistent strivings for mediation should not be understood in terms of a search for reconciliatory interim solutions but rather as a working out of the dialectical synthesis in the proper meaning of a »third and real solution ${ }^{18}{ }^{8}$ to the above mentioned, virtually false dilemmas; a solution that in Lukács' case was not possible before socialism had been achieved. Finally, his perseverance in socialist perspectives for liberation also in light of socialism's historical defeats was what has rendered his late aesthetics unintelligible to the aesthetic thought designed in conditions of Cold War capitalism and haunted by fundamental contradictions of committed art resulting therefrom. ${ }^{19}$

The line of my argument leads from the widely accepted opinion that Lukács' early aesthetics gestured towards the necessity to act against alienation, over an account of his revolutionary contributions to the struggle for the liberation of humankind (expressed in terms of politics as well as aesthetics), towards his late retake and reworking of issues that were occupying him throughout the earlier stages of critical activity. The apodictic assumptions that underpin Lukács' aesthetics and politics as a whole are as follows: First, human beings are social animals that create their own history. They are active not only through their work and labor but also through their cognitive, epistemological, and anthropological construal of the world they participate in and create through their social interaction. Second, as the opaque system of capitalist production renders individual attempts at understanding social reality impossible, it is only by means of strict epistemological procedures (provided first and foremost by scientific socialism) that social reality can be comprehended in its totality.

One major failure of bourgeois ideology - including philosophy, political economy, and the practices of quotidian life - has been the misapprehension of this totality. For Lukács, "what is false is not so much the content of classical middle-class philosophy as its form «, ${ }^{20}$ meaning that the bourgeois methodology isolated particular problems emerging in specific political and social constellations, without being able to grasp their historical and social dimension or to offer systemic critiques. Carriers of ideology intuitively worked against the understanding of the overall formal dimension of the phenomena in question and were, as a consequence, even

17 Cf. ibid., p. 308.

18 Lukács: The Young Hegel, p. 521.

19 As regards other reasons for this unintelligibility, especially with respect to his understanding of totality and the revolutionary role of the proletariat, cf. Hartley: Politics of Style, pp. 173-177.

20 Jameson: The Case for Georg Lukács, p. 183; cf. Bernstein: The Philosophy of the Novel, pp. 11-12, 68-69. 
hostile to changing them in any essential way. Third, one fundamental claim of Lukács' aesthetics is that art, which is an epistemological domain strictly separated from science and in that respect "specific " (eigenartig), ${ }^{21}$ makes an important contribution to the emancipatory progress of humankind inasmuch as it reflects the human world in its own, evocative way. ${ }^{22}$ It is primarily in this evocative sense that »every art is realistic « ${ }^{23}$ Simultaneously, by means of employing art's specific forms and procedures (calibrated according to the system of art's own presuppositions, rules, and material conditions), individual artworks not only reflect the human world, but are also able to impact this world and alter it. Thereof consists art's not only strictly aesthetic but also its implicit social, ethical, and political commitment and, unambiguously, the possible link between Lukács' Die Eigenart and his early and mature aesthetics.

\section{2. `Early`, `Mature`, and `Late`Lukács}

The aforementioned tripartite compartmentalization of Lukács' opus in his early, mature, and final or late phase is also bound to suggest that his mature and late aesthetics of content - alongside the motto "Das determinierende Prinzip ist der Inhalt $\aleph^{24}$ - stand out as irreconcilable with his early philological and philosophical interests in literary forms. This enforced yet common contrasting of the presumptively purely aesthetic concerns with the subsequent conversion to revolutionary contents, in whose backwash art should commit itself, falls short of one decisive dimension of form that continues to reverberate within all of Lukács' theoretical endeavors. In his early work, the form is, namely, revealed not only as an asset of literary genres, or as a formal dimension of particular artworks, or even as »the essence of whatever has to be said «, ${ }^{25}$ but already as a way of mastering life: The bourgeois subject masters life by means of a willing subordination to the rules that establish and uphold rather uneventful and tedious everyday

21 On the differences and common goals of art and science, cf. Lukács: Soul and Form, p. 18 (Die Seele und die Formen, p. 7); otherwise Lukács: Die Eigenart I, p. 483.

22 Lukács: Die Eigenart I, p. 704.

23 In the most general sense, every art is realistic (Lukács: Die Eigenart II, p. 804) because it unavoidably - under the condition that it is art - represents the tendencies of its particular historical time and social place.

24 Lukács: Die Eigenart I, p. 412.

25 Lukács: Soul and Form, p. 166 (»[D]ie Form ist eine so weit verdichtete Essenz alles zu Sagenden, daß wir nur mehr die Verdichtung herausfühlen, und kaum mehr, wovon sie die Verdichtung ist.", Die Seele und die Formen, p. 307). 
life. This controlled and controlling life requires "cutting down the conduct of one's life to a strictly and narrowly bourgeois measure «, ${ }^{26}$ with its heroes abiding by " $[\mathrm{t}]$ he things which befall them, not the things they do ${ }^{27}{ }^{27}$ By contrast, the modern artist and philosopher, insurmountably opposed to this »bourgeois way of life «, ${ }^{28}$ uses the form as a refuge from forfeited life. ${ }^{29}$ In this sense, the aesthetic form is employed as an intervention into the order of quotidian, compromise-oriented life management. It is already here that the ethical and potentially political problem of Lukács' early work arises: His interest in aesthetic forms emerged, in fact, as a manifestation of an "attempt to come to grips with the contradictions of the aesthetic and ethical modes of life within a collapsing social world «. ${ }^{30}$ Read in this vein, Lukács' early cultural criticism not only presaged the diagnosis of History and Class Consciousness (1923) - the loss of totality, visible in the obfuscation of the insight into reality and a semi-religious, contemplative attitude toward products of human creativity and social interrelations - but also laid the groundwork for his lifelong insistence on the imperative of an >ought Initially voiced in the ideological framework of German phenomenology and individualist psychology, this imperative was soon substantiated with a political, specifically revolutionary rationale. After the watershed that occurred with The Theory of the Novel and shifted his »tragic world view $\ll^{31}$ towards a principle or even an imperative of hope, ${ }^{32}$ throughout all of his phases Lukács sustained his allegiance with the maxim: »Du mußt dein Leben ändern! «33 The final formulation of this >ought $\iota$ or >Du-mußt principle is submitted in Die Eigenart des Ästhetischen and reads as follows:

Auch das idyllischste Lied oder das einfachste Stilleben drückt in einem bestimmten Sinn ein Sollen aus; es richtet sich an den Menschen des Alltags mit der Aufforderung, jene

Ibid., p. 74 (»das Niederschrauben der Lebensführung auf das Maß des streng Bürgerlichen«, Die Seele und die Formen, p. 122).

27 Ibid., p. 84 (»Das, was ihnen widerfährt — nicht das, was sie tun«, Die Seele und die Formen, p. 143).

28 Ibid., p. 74 (»Bourgeoisdasein«, Die Seele und die Formen, p. 123).

29 For the difference between the categories of `life cation of Aesthetics and Ethics, pp. 164-165): »The categories of >life and >living signify that a distinction is to be made between the bare fact of personal existence and the form or value through which life becomes meaningful. >Living « is an expression of the life of the soul which is objectified in artistic forms."

30 Ibid., p. 163.

31 Löwy: Georg Lukács, p. 97.

32 Ibid., p. 109. For Lukács' later criticism of this tragic stance (and especially of Georg Simmel), cf. Jay: Marxism and Totality, pp. 107-108.

33 Lukács: Die Eigenart I, p. 779. 
Einheit und Höhe, die im Werk verwirklicht erscheint, ebenfalls zu erreichen. Es ist das Sollen jeden erfüllten Lebens. ${ }^{34}$

Although this did not seem so from the perspective of 1911, the ideological analyses of History and Class Consciousness were merely one step away from the cultural criticism deployed in Soul and Form. The step that came in between was The Theory of the Novel, of which Jay M. Bernstein, who made an unequivocal case for interpreting Lukács' "pre-Marxist theory of the novel from the perspective of his Marxist social theory «, ${ }^{35}$ said that there we already "have the rudiments of a Marxist theory of the novel «. ${ }^{36}$ Clearly, in Soul and Form Lukács was not yet able to argue against a »metaphysische[] Überspannung der Selbstständigkeit « ${ }^{37}$ of the sphere of art. Nevertheless, although he was far from explicitly stating that art arises "aus der breiten Basis des Alltagslebens $\aleph^{38}$ and that its results, in the end, flow back again to everyday life (which again renders the independency of the sphere of art merely »relative «), ${ }^{39}$ the analyses in Soul and Form registered a $»$ zeitpsychologisch ${ }^{40}$ crisis and discussed art and literature in close exchange with society. They also evinced the realistic »Grundfaktum $\aleph^{41}$ of the indispensable material origins of the quotidian aesthetic sensible: »historical feelings were for them [bourgeois writers] life-feelings «. ${ }^{42}$ Simultaneously, art as human praxis was understood not as a historically and socially unencumbered phenomenon of universal artistic value but unambiguously

Ibid., pp. 481-482. Cf. the related romantic imperative in Soul and Form: »It is the ancient dream of a golden age. But their golden age is not a refuge in a past that has been lost forever, only to be glimpsed from time to time in beautiful old legends - it is a goal whose attainment is the central duty of everyone.« (p. 65) (»Es ist der uralte Traum von einem goldenen Zeitalter. Doch ihr goldenes Zeitalter ist kein ewig verlorener Hort vergangener Zeiten, der nur noch in schönen Märchen manchmal spukt, es ist das Ziel, dessen Erreichen jedermanns Lebenspflicht ist. «, Die Seele und die Formen, p. 104)

Bernstein: The Philosophy of the Novel, p. viii; cf. p. 42.

36 Ibid., p. x. Bernstein concurs with Fredric Jameson, who in The Theory of the Novel discerns elements of a "shift from a metaphysical to a historical view of the world that will be ratified by Lukács' conversion to Marxism « (Jameson: The Case for Georg Lukács, p. 182). Jameson also posits that »if Lukács became a Communist, it was precisely because the problems of narration raised in the Theory of the Novel required a Marxist framework to be thought through to their logical conclusion « (ibid.).

37 Lukács: Die Eigenart I, p. 489.

38 Ibid., p. 488.

39 Ibid., cf. pp. 483-484.

40 Lukács: Die Seele und die Formen, p. 136.

41 Lukács: Die Eigenart I, p. 488.

42 Lukács: Soul and Form, p. 81 (»[Das heißt,] daß bei ihnen die historischen Empfindungen zu Lebensgefühlen, zu praktisch wirksamen Lebensfaktoren geworden waren [...].«, Die Seele und die Formen, p. 137). 
also as a materialization of a particular historical subject: »In their works, the bourgeois way of life assumes historic stature. « ${ }^{43}$

What is usually referenced to as Lukács' pre-Marxist romantic anti-capitalism ${ }^{44}$ was not an individual inclination but a hallmark of a generation; an aesthetic reaction to the loss of totality as a mourned `Obdach $\prec \cdot{ }^{45}$ Once the shelter from the incertitude of modern life disappeared and »the river beds, now dry beyond all hope, have marked forever the face of the earth $"{ }^{46}$ the concept of totality came to represent the forsaken certainty and an almost pantheist identity with the whole - humanity, genus, lifeworld. ${ }^{47}$ It is with respect to the idea of totality, I recur, that the early problem of form, which gestured towards problems of ethics, prefigured not only Lukács' soon conversion to Marxism, but opened up a set of conceptual configurations that were readopted in his late aesthetics. Within this framework, Die Eigenart emerges as a critical resumption of the early problems of ethics and their integration in the setting of political and aesthetic solutions that Lukács subsequently proposed and agreed to in the post-revolutionary decades. Here, it is the viewpoint of specifically socialist totality that proves to be determining: If the early ethical problem - crystallized in the question »how can life become essence ${ }^{48}$, become meaningful (»wesenhaft $)^{49}$ - was doomed to remain unresolved, in the subsequent decades it was the perspective of socialism that allowed for solutions to this typically modern conundrum. In 1953, when he was already working on his aesthetic "grande ovre de synthèse $"{ }^{50}$ particular episodes of the magnificent project of establishing socialism may have seemed flawed, but for Lukács this did not diminish socialism's historical and global significance. In Die Eigenart's final chapter (»Der Befreiungskampf der Kunst «), ${ }^{51}$ he conceded that building socialism was by no means an easy task:

Darin steckt die von uns dargestellte Schwierigkeit: im Sozialismus, in der sozialistischen Kultur jene Kraft aufzuzeigen, die imstande ist, diesen Befreiungskampf siegreich zu Ende zu führen. [...] Die Frage, in der unsere Betrachtungen kulminieren, ist die einer welthistorischen Perspektive. [...] Für uns kommt es auf die Perspektive der Gesamtentwicklung an [...]. ${ }^{52}$

Ibid. (»In ihren Werken wird das Bürgertum historisch.", Die Seele und die Formen, p. 138)

Löwy: Georg Lukács, p. 97; Jay: Marxism and Totality, p. 85; Rees: Introduction, p. 4; Butler: Introduction, p. 1.

Cf. Lukács: The Theory of the Novel, p. 41; Lukács: Die Theorie des Romans, p. 32.

Ibid., p. 38 (»[D]ie hoffnungslos ausgetrockneten Strombetten haben das Antlitz der Welt für immer zerklüftet.«, Die Theorie des Romans, p. 30).

On totality as Lukács' continuous obsession, cf. Jay: Marxism and Totality, pp. 301-302.

Lukács: The Theory of the Novel, p. 30.

Lukács: Die Theorie des Romans, p. 22, 27.

Göcht: Mimesis - Subjektivität - Realismus, p. 49, cf. p. 35; cf. Lukács: Die Eigenart I, p. 25.

Lukács: Die Eigenart II, pp. 648-835.

Ibid., p. 833. 


\section{Irreconcilable Counterparts: Early Aesthetics and Ethics}

Although with the benefit of hindsight one can entertain a claim that in his early years Lukács already acted as a "revolutionary without a revolution «, 53 it is glaringly apparent that the only viable path for him in the pre-1918 period was the aesthetic one. As John Rees suggests in his Introduction to the new edition of the essay Tailism and the Dialectic (1926/2000), in this period there was hope that $»[\mathrm{p}]$ erhaps brief moments of artistic experience might overcome the alienation from modern political forms $«{ }^{54}$ Yet the considered aesthetic solutions were not possible precisely because the problems were defined from the standpoint of aesthetics exclusively. That said, the whole project of Soul and Form rose and fell due to its limitation to aesthetic approaches. Even if the respective essays did not delimit themselves to aesthetic matters (as if this were possible in the first place), but already systematically touched upon ethical issues - upon matters of s soul rather than those of >form ‘ exclusively - the fallacious stance of an reither-art-orlife a aesthetics precluded both interpersonal ethics and collective politics and thus served as both the outset and the endpoint of analysis. ${ }^{55}$ As for our contemporary problems, the significance of Soul and Form lies precisely in its »suggestion that aesthetics alone fails to provide analogues for personal, social and, especially, political life $«^{56}$ - which is a suggestion that is insufficiently acclaimed in belabored discourses on what in common parlance is called the >politics of aesthetics` (e.g., in the laudatory reception of Jacques Ranciere). ${ }^{57}$ In contrast to Soul and Form's negative diagnoses, Die Eigenart unambiguously acclaimed ethics as the final criterion:

Überhaupt ist die Ethik das eigentliche Gebiet für den realen Entscheidungskampf zwischen Diesseitigkeit und Jenseitigkeit, für die reale aufhebend-aufbewahrende Umgestaltung der menschlichen Partikularität. Eine endgültige Antwort auf die hier auftauchenden Probleme kann also nur in einer Ethik gegeben werden..$^{58}$

At the core of both The Theory of the Novel and Soul and Form stands a belief that in modernity, art and life necessarily part ways; their fusion

Arato/Breines: Young Lukács, pp. 3-12. For a critical assessment of such a »linear continuity of Lukács' moves from aesthetics to ethics to politics«, cf. Crow: Form and the Unification of Aesthetics and Ethics, pp. 161-162.

54 Rees: Introduction, p. 4.

55 Cf. ibid. On the »standpoint of art«, cf. Lukács: Soul and Form, p. 99.

56 Crow: Form and the Unification of Aesthetics and Ethics, p. 176.

57 For critical voices, cf. Sonderegger: Neue Formen der Organisierung; Ventura: Gegen Kunsttheorie; Perica: Aisthesis verorten.

58 Lukács: Die Eigenart II, p. 800. Ethics reappears as decisive for the so-called »vermittelnde Mitte not only in aesthetics but also in law theory. Cf. Die Eigenart II, p. 201. 
either leads to a violent reconciliation (annihilation of art through forms of compromised ordinariness) or to a likewise violent artistic renunciation of the forms of quotidian life. If the first option is made at the price of the aforementioned »cutting down the conduct of one's life to a strictly and narrowly bourgeois measure $"{ }^{59}$ the second decision is made for the sake of a real, that is, »honest « (»ehrlich «) ${ }^{60}$ life. In Soul and Form's essay on »the seducer ", Sören Kierkegaard, and »the jilted girl «, ${ }^{61}$ his fiancée Regine Olsen, ${ }^{62}$ we encounter an opposition of the "merely relative " and the "absolute ${ }^{63}{ }^{6}$ life - an opposition that leans against the logic of an irresolvable seither-or . This binary logic reemerges on many later occasions, for instance in the opposition of »man « and $»$ troll $«,{ }^{64}$ or in the distinction between »Kern « and Schale $«{ }^{65}$ With the risk of preempting myself, allow me to remark that although my claim on the synthetic procedures of Die Eigenart des Ästhetischen suggests a dismissal of this either-or logic that constituted the liberal Lukács to the same extent as the Marxist Lukács, the real significance of Die Eigenart lies in a by no means paradoxical maintaining of the reither-or logic and a simultaneous transmission of this logic onto another level of argumentation, as well as in a substantiation of this logic on a less political and rather profoundly anthropological basis.

There is, however, a dimension that sets Soul and Form apart from all Lukács' later works. ${ }^{66}$ If The Theory of the Novel recognized art (literature) as potentially successful on its way towards a revolutionary transformation of the quotidian, fragmented »whole man« (»ganzer Mensch») towards the utterly human »man as a whole» (»Mensch ganz «), ${ }^{67}$ in Soul and Form it was blatantly obvious that »there is no point in-between « ${ }^{68}$ In this regard, Kierkegaard's high-handed position was admittedly only romantic and sentimental. ${ }^{69}$ This

60 Ibid., p. 45 (Die Seele und die Formen, p. 64).

61 Ibid., p. 47 (»der Verführer und das verlassene Mädchen«, Die Seele und die Formen, p. 68).

62 "The Foundering of Form Against Life: Søren Kierkegaard and Regine Olsen«, ibid., pp. 44 -58 (»Das Zerschellen der Form am Leben: Sören Kierkegaard und Regine Olsen«, Die Seele und die Formen, pp. 61-90).

63 Ibid., p. 47 (Die Seele und die Formen, p. 69).

64 The opposition stems from Henrik Ibsen's play Peer Gynt, with the troll abiding by the motto »Troll, sei dir selbst genug« (Lukács: Die Eigenart II, p. 381).

65 Cf. the chapter »Der Mensch als Kern oder Schale« (Lukács: Die Eigenart I, pp. 740-764).

66 For a comprehensive elaboration on the sspecificity< of the Specificity of the Aesthetic in the context of Lukács' work as a whole, cf. Johnson: Die Eigenart des Aesthetischen.

67 Cf. the chapter »Homogenes Medium, der ganze Mensch und der `Mensch ganz« (ibid., pp. 606-635).

68 Löwy: Georg Lukács, p. 102.

69 Lukács: Soul and Form, p. 51 (Die Seele und die Formen, p. 77). 
brings Kierkegaard close to Novalis and the circle of German poets around the journal »Athäneum « ${ }^{70}$ of whom Lukács maintained that » $[\mathrm{t}]$ he actual reality of life vanished before their eyes and was replaced by another reality, the reality of poetry, of pure psyche. They created a homogeneous, organic world unified within itself and identified it with the real world. $\aleph^{71}$ What Lukács claimed about the Romantic generation is applicable also to the romantic anti-capitalism of his own intellectual and social belonging: A retreat into aesthetic discussions functioned not only as a signal of the loss of reality, but was also by the same token inscribed in the very social condition of the autonomy of art in capitalist modernity; and it was only at the price of losing the precise relation of art and life that the erecting of a coherent and organic world of art and poetry became possible. ${ }^{72}$ Therefore, although in Soul and Form one cannot ignore the presence of a »Spannung zwischen Fülle des Möglichen und Bestimmtheit des Wirklichen $"{ }^{73}$ of a "Verhältnis zwischen rationalem Erfassen und der irrationalen Hingabe $«{ }^{74}$ or of a irreconcilable rift between Eckhardtian vita activa and vita contemplativa, ${ }^{75}$ one also cannot determine any indicator of a synthetic junction of these opposites.

The irreconcilability of the two constituents of an opposition, of thesis and antithesis, is the decisive theoretical procedure in Soul and Form: »The difference is whether the life-problems of a particular life arise in the form of an either/or, or whether as well as` is the proper formula when the split appears. ${ }^{76}$ For Kierkegaard, the decision was to create life according to

70 Cf. the essay »On the Romantic Philosophy of Life: Novalis«, ibid., p. 59-72 (»Zur romantischen Lebensphilosophie: Novalis«, Die Seele und die Formen, pp. 91-119).

71 Ibid., p. 67 (»Die tatsächliche Realität des Lebens entschwand vor ihren Blicken und wurde von einer anderen, von der poetischen, der rein seelischen ersetzt. Sie schufen eine homogene, in sich einheitliche und organische Welt und identifizierten diese mit der tatsächlichen.«, Die Seele und die Formen, p. 109).

72 In The Theory of the Novel, one reads a claim on Novalis that is by the same token applicable to young Lukács' historical time and ideological and social space: »His reality is so much weighed down by the earthly gravity of idealessness, his transcendent world is so airy, so vapid, because it stems too directly from the philosophico-postulative sphere of pure abstraction, that the two are unable to unite in a living totality." (p. 140) (»Die Wirklichkeit ist allzu behaftet und beladen von der Erdenschwere ihrer Ideenverlassenheit, und die transzendente Welt ist zu luftig und inhaltslos wegen ihrer allzu direkten Abstammung aus der philosophisch-postulativen Sphäre des abstrakten Überhaupt, als daß sie sich zur Gestaltung einer lebendigen Totalität organisch vereinigen könnten.«, Die Theorie des Romans, p. 125)

73 Largier: Zeit der Möglichkeit, p. 12.

74 Ibid., p. 13.

75 Ibid., p. 24, 81.

76 Lukács: Soul and Form, p. 47 (»Dies ist der Unterschied, ob die Lebensprobleme in der Form von sentweder - oder ‘ aufgeworfen sind, oder ob ssowohl als auch ‘ der wirkliche Ausdruck dafür ist, wenn sich die Wege einmal zu verzweigen scheinen.", Die Seele und die Formen, p. 69). 
the principles of honesty, that is, of art. No reconciliation (let alone sunder duress $\triangleleft$ ) and no "petty compromises $~^{77}$ were conceivable. Although one can forefeel the strictness and radicalism of Lukács' later political and ideological solutions to social problems, here it was art and only art that offered »salvation from loneliness and chaos ${ }^{78}{ }^{78}$ Thus, the fundamental principle of Lukács' early aesthetics - according to which only »the form of individual life $«^{79}$ was able to »embrace the totality of life ${ }^{80}$ - was captured in a deadlock: The poet's life form remained relentless in light of the quotidian obstinacy of the bourgeois forms of life; and vice versa, the life content was too resistant to be subdued to the design of an art form. As a consequence, the aesthetic proved to be unable to seize life and render it meaningful. In contrast to the subsequent period, when it became clear that the embraced revolutionary politics, alongside its aesthetics, was viable only and exclusively when it acted as the »servant of ethics,$^{81}$ in Soul and Form no such ranking is discernible.

In The Theory of the Novel, however, the estimation of art's distance from society altered. Here, the novel was claimed to mimetically reflect the ethical problems of the epoch; simultaneously, thanks to a specifically human intellectual objectification (Vergegenständlichung) it was also rendered capable of intervening in its own time and space. After the identity of the individual and the whole had ceased to hold sway over humanity and as it could not, under any circumstances, be regained, it was only the novel - »essentially an epic form of the very impossibility of epic ${ }^{82}$ - that could attempt a contribution to the search for the forlorn total experience. This should not be understood as a resurrection of paradise lost but as a modern, updated production of a non-transcendent, this-worldly home (»diesseitige[] Heimat «). ${ }^{83}$ Therefore, if it is understood that Soul and Form "culminate[d] in the revelation of the failure of form and the inadequacy of its aesthetic expression to represent life $«,{ }^{84}$ it is in The Theory of the Novel that the novelistic form obtained its proper Lukácsian »ethical significance $:^{85}$ » This aesthetic problem, however, is at root an ethical one, and its artistic solution therefore presupposes, in

Ibid., p. 48 (»flache[] Kompromisse«, Die Seele und die Formen, p. 71).

Ibid., p. 67 (»die Rettung aus der Einsamkeit und aus dem Chaos«, Die Seele und die Formen, p. 108).

Crow: Form and the Unification of Aesthetics and Ethics, p. 176.

Ibid.

Löwy: Georg Lukács, p. 127.

Bivens: Epic and Exile, p. 10.

Lukács: Die Theorie des Romans, p. 117.

Crow: Form and the Unification of Aesthetics and Ethics, p. 171.

Jameson: The Case for Georg Lukács, p. 173; cf. Löwy: Georg Lukács, p. 99. 
accordance with the formal laws of the novel, that a solution has been found to the ethical problem. $\ll^{86}$ This solution - and this is the turning point in Lukács' argumentation - already implies the imperative that a "rounded correction of reality be translated into actions $«{ }^{87}$ Yet although the critical potential for ethical and political intervention begins to emerge here, this does not mean (and for Lukács would never mean) that the novel alone can offer feasible solutions to the overall problems detected: »To create, by purely artistic means, a reality which corresponds to this dream world, or at least is more adequate to it than the existing one, is only an illusory solution. ${ }^{88}$ The novel merely contains and preserves a seemingly lost relation to totality, moreover, it literally »thinks in terms of totality «. ${ }^{89}$ Nevertheless, in the same way as the central character of the novel is rendered problematic ${ }^{90}$ and in the same way as the aforementioned »actions « are feasible merely as actions that "prove the individual's right to self-sufficiency «, ${ }^{11}$ so does totality in the novel emerge not as a political or community project but as a problem. ${ }^{92}$ For instance, Lukács was explicit about the fact that the modern novel of education designs a hero who "accommodates himself to society by resigning himself to accept its life forms « ${ }^{93}$ Thus, the novel exhibits a man whose accommodation in the given world is

neither a protest against it nor an affirmation of it, only an understanding and experiencing of it which tries to be fair to both sides and which ascribes the soul's inability

Lukács: The Theory of the Novel, p. 115 (»Dieses ästhetische Problem ist jedoch in seinen letzten Wurzeln ein ethisches; seine künstlerische Lösung hat deshalb - den Formgesetzen des Romans entsprechend - das Überwinden der ethischen Problematik, die es verursacht, zur Voraussetzung. «, Die Theorie des Romans, p. 101). Lukács returns to this appreciation of The Theory of the Novel in the preface of Die Eigenart des Ästhetischen (I, p. 25): "Schon die >Theorie des Romans`, entstanden im ersten Kriegsjahr, richtet sich mehr auf geschichtsphilosophische Probleme, für welche die ästhetischen nur Symptome, Signale sein sollten. Dann traten Ethik, Geschichte, Ökonomie immer stärker in den Mittelpunkt meiner Interessen. Ich wurde Marxist, und das Jahrzehnt meiner aktiven politischen Tätigkeit ist zugleich die Periode einer inneren Auseinandersetzung mit dem Marxismus, die seiner wirklichen Aneignung."

87 Lukács: The Theory of the Novel, p. 115 (»[...] kann diese abgeschlossene Korrektur der Wirklichkeit sich in Taten umsetzen [...] «, Die Theorie des Romans, p. 101).

88 Ibid. (»Das rein künstlerische Schaffen einer Wirklichkeit, die dieser Traumwelt entspricht oder ihr wenigstens angemessener ist als die tatsächlich vorgefundene, ist nur eine scheinbare Lösung.", Die Theorie des Romans, p. 101)

89 Ibid., p. 56 (»[...] Gesinnung zur Totalität hat«, Die Theorie des Romans, p. 44).

90 Ibid., p. 136 (Die Theorie des Romans, p. 147).

91 Ibid., p. 115 (»das Recht des Individuums auf diese Selbstherrlichkeit«, Die Theorie des Romans, p. 120).

92 Ibid., p. 56 (Die Theorie des Romans, p. 44).

93 Ibid., p. 136 (»das Sichabfinden mit der Gesellschaft im resignierten Aufsichnehmen ihrer Lebensformen«, Die Theorie des Romans, p. 147). 
to fulfil itself in the world not only to the inessential nature of the world but also to the feebleness of the soul. ${ }^{94}$

And so it came about that only after the final conclusions of The Theory of the Novel had been drawn, the "frontier between literature and politics, aesthetics and revolution ${ }{ }^{95}$ could take its course. Henceforth, it was not aesthetics but politics that was assigned the duty to liberate the world, and it was unreservedly determined by ethics as its leading principle. ${ }^{96}$ The notoriously secondary status of literature resulting hereof nurtured accusations that for Lukács, literature ostensibly served as a mere ancilla of politics; his contemporary warnings that art and literature cease to be autonomous domains as soon as they are used as plain ideological tools or illustrations of social and political contents continue to be ignored in these accusations. ${ }^{97}$ In contrast to this difficult international reputation, Lukács warned against the »net of contradictions (»Fangnetz der Widersprüche «) $)^{98}$ early on: he claimed that artworks can - and are in fact obliged to - avoid the erroneous opposition between "pure art ( or »Formvollendung «) and »tendency «. ${ }^{99}$ This claim was to reemerge in his late aesthetics in terms of a more straightforward claim on the social commitment of artworks only and exclusively as autonomous artifacts. That said, in his perspective, the political suses of literature can be pondered upon only under the condition that literature acts as literature. The reason why Lukács continues to be cast as a dogmatic thinker is that it was not until his late - and unread - Die Eigenart that he succeeded in elaborating on the specificity of this as and to find it in art's typically human evocation, as well as in the synthetic procedures provided by its so-called homogenous medium, which is defined as follows:

Ein homogenes Medium im Sinne der Ästhetik kann nur gebildet werden, wenn das anfängliche Einengen der Widerspiegelung der Wirklichkeit und das, was durch diesen spezifischen Sinn wahrnehmbar ist, nur ein Mittel dazu bildet, einen zugleich spezifischen

94 Ibid. (»[...] weder ein Protest dagegen noch seine Bejahung: nur ein verstehendes Erleben; ein Erleben, das gegen beide Seiten gerecht zu werden bestrebt ist und das in dem Sich-nichtauswirken-Können der Seele in der Welt nicht nur die Wesenlosigkeit dieser, sondern auch die innere Schwäche jener erblickt.", Die Theorie des Romans, p. 148) Löwy: Georg Lukács, p. 111.

96 This applies to Lukács' political activism as well. He even »sought to analyze Bolshevism as if he were still answering the old problem of how a person can behave ethically in a totally sinful world « (Rees: Introduction, p. 9). In the course of the post-revolutionary discussions in the Third International, this turned out to be a stumbling block that compelled Lukács to exert self-criticism. Cf. Lukács: Tailism and the Dialectic.

97 Cf., for instance, a remark by Juliane Rebentisch, namely that Lukács' »model reduces the function of art to illustrating vividly what has already been understood «(Realism Today, p. 248). 
und totalen Aspekt der Welt in der so entstandenen neuartigen Weise abzubilden und sinnbildlich festzuhalten. [...] Das homogene Medium ist deshalb nur in seiner ersten Unmittelbarkeit ein bloß formales Prinzip. ${ }^{100}$

It follows that for the pursuit of a >continuity thesis $<$ - deployed not only by a series of theoreticians such as Andrew Arato, Werner Jung, Gyorgy Marcus, or Pauline Johnson, ${ }^{101}$ but asserted also by Lukács himself ${ }^{102}$ - the term `romantic anti-capitalism ^ does not suffice as a qualification that could consolidate Lukács' early cultural criticism with the subsequent stages of his intellectual development. Concomitantly, to insist on form as a red thread in Lukács' long work would underexpose the form's dialectical relationship with the content, without which no form would be thinkable in the first place. Although statements such as »the essay has a form which separates it, with the rigor of a law, from all other art forms « $^{103}$ may support a formalistic reading of Soul and Form, what relates these essays to all of Lukács' later theoretical interventions is not just a formal account of art forms but more especially the interest in an integrative form-content unity. As adumbrated above, ,form indeed appears first in the dimension of an ethics of the self, i.e., in the sense of mastering life. Secondly, it is discussed in its materialistic relation to the content, precisely as a form that $»$ is not added on to expression, but becomes its condition, the sign and possibility of its subjective and objective truth «. ${ }^{104}$ These early properties of the form reappear in Die Eigenart des Ästhetischen in an almost unaltered guise; the form adjoins with the content in a way that »die ästhetische Form [...] stets die Form eines bestimmten Inhalts ist «. ${ }^{105}$ However, in Die Eigenart, this mediating form-content-unity carries wider social significance, which in Soul and Form proves to be inexistent. Here, I believe that Die Eigenart's social extension of form-content-unity can be inter-

100 Lukács: Die Eigenart I, p. 611.

101 Cf. Göcht: Mimesis - Subjektivität - Realismus, pp. 33-50.

102 Lukács: Gelebtes Denken, p. 132: »Bei mir ist jede Sache die Fortsetzung von etwas. Ich glaube, in meiner Entwicklung gibt es keine anorganischen Elemente."

103 The full quote reads as follows: »I speak here of criticism as a form of art, I do so in the name of order (i.e., almost purely symbolically and non-essentially), and solely on the strength of my feeling that the essay has a form which separates it, with the rigor of a law, from all other art forms. I want to try to define the essay as strictly as is possible, precisely by describing it as an art form. (Lukács: Soul and Form, p. 17, emphasis I. P.) (»Wenn ich aber hier von dem Essay als einer Kunstform spreche, so tue ich es im Namen der Ordnung (also fast rein symbolisch und uneigentlich); nur aus der Empfindung heraus, daß er eine Form hat, die ihn mit endgültiger Gesetzesstrenge von allen anderen Kunstformen trennt. Ich versuche den Essay so scharf wie überhaupt möglich zu isolieren eben dadurch, daß ich ihn jetzt als Kunstform bezeichne.«, Die Seele und die Formen, p. 5)

104 Butler: Introduction, p. 2.

105 Lukács: Die Eigenart I, p. 758. 
preted as a reverberation of his early $>$ formalistic $<$ interests - a reverberation that is, however, unthinkable without taking into account the inherited assets of Lukács' subsequent turn to Marxism and revolutionary politics.

\section{Synthetic Procedures in Die Eigenart des Ästhetischen}

Placing his arguments at a critical distance from mechanicist understandings of reflection theory, in Die Eigenart Lukács reached out for the dialectical method of negation of negation: There, the condemnation of liberal aesthetics, typical for the interwar cultural left, was rectified with a stance in support of those strings of the liberal tradition that provided socialist art with dimensions which warrant its status as art, without however compromising it with subjectivism, fatalism, and magical or allegorical interpretations of reality. By doing so, Lukács safeguarded the aesthetic against the utilitarian demands on committed and revolutionary art that tended to subject the aesthetic realm to a political tooling:

Und in verständlicher Opposition dagegen wurde nun in verschiedenen Richtungen, von der vulgären Tendenzkunst und der sogenannten >littérature engagée bis zur Auffassung vieler Theoretiker der sozialistischen Parteilichkeit, sehr zum Schaden des Verständnisses dessen, was an der Kunst wirklich künstlerisch ist, das relativ Berechtigte der Interesselosigkeit als Moment im ästhetischen Gesamtprozeß einfach eliminiert. ${ }^{106}$

Although it may seem to the inexperienced eye that Lukács thus repudiated his own earlier positions, he in fact reinforced a synthetic procedure that ripened as early as in History and Class Consciousness - a synthesis of politics and ethics he was compelled to dismiss after scathing criticism from the critics of the Third International. ${ }^{107} \mathrm{~A}$ similar attempt at synthesis and its subsequent dismissal was to an extent restaged after the appearance of his $1928 »$ Blum-Theses«, originally a political program proposed to the Hungarian Communist Party, which turned out to be as "premature ${ }^{108}$ as the theoretical step forward from 1923.

If these synthetic procedures were strongly rejected by the Third International, they were, in different ways and for different reasons, also largely ignored by the adherents of Lukács' revival in the 1960s: The specifically aesthetic procedures of synthesis, as elaborated in Die Eigenart des Ästhetischen, remained below the radar of international socialist intellectual forces that were primarily interested in the political treatise History and

106 Ibid., p. 616.

107 Cf. Lukács: Tailism and the Dialectic.

108 Rees: Introduction, p. 30. 
Class Consciousness. One of the reasons for a shift of focus away from a systemically thought-through Marxist aesthetics was that in the 1960s the idea of art that could dutifully make its own contribution to the liberation of humankind was radically abandoned, which was a side effect of the dismissal of the classical concept of political revolution in favor of an aesthetically marked subversion. Namely, Western intellectuals had already become accustomed to the stance that "art under capitalism is art under capitalism $\ll^{109}$ and considered alternatives, if not as entirely impossible, as necessarily entertaining a harrowing series of paradoxes. In return, » $[t]$ he end of political illusions [...] retroactively shed light on the end of aesthetic illusions ${ }^{110}$ So it came about that while Lukács in the socialist East enjoyed the status of a tolerated persona non grata, in the capitalist West, apart from valuable exceptions, he was also being read only selectively. ${ }^{111}$

In his late aesthetics, Lukács argued against a Manichean opposition of form and content (or, expressed in his early terminology, of `form ‘ and ssoul«) because it adheres to a system of "false extremes «. ${ }^{112}$ As remarked above, Lukács' thinking in dichotomies was, in fact, never marked by sheer exclusivism: Even if in Soul and Form the »Horizont der Vermittlung ${ }^{113}$ was rendered hopelessly inaccessible and any attempt at mediation discarded as futile, in the treatise on the essay ${ }^{114}$ we, in fact, encounter adumbrations that recently have been recognized as a »Suspendierung sowohl der Enthebung ins Allgemeine wie auch der Absorption durch das Besondere «. ${ }^{115}$ Simultaneously, it would be false to assume that the early interest in forms outweighed the importance of contents, or that in the subsequent decades this constellation abruptly changed. What changed in time was not the question of primacy

109 Roberts: Revolutionary Time and the Avant-garde, p. 224.

110 Rockhill: Radical history, p. 97. Cf. Arato/Breines: Young Lukács, pp. 224-225; Anderson: Considerations on Western Marxism, p. 7, 9.

111 It should be recalled that among those who shaped Western Marxism, Lukács was the only one to make the unique decision of migrating eastward (Jay: Marxism and Totality, p. 5). For a background on the reservations held about Lukács in postwar capitalist societies, cf. Jameson's Reflections in Conclusion (esp. pp. 202-203) and, unavoidably, Perry Anderson's canonic script on Western Marxism. Cf. also another related claim by Jameson: „[...] Only it is easy to see why Western thinkers have on the whole preferred the concept of alienation: the latter permits the diagnosis of an evidently fallen and degraded reality without demanding of the mind any reciprocal attempt to imagine a state in which man no longer is alienated." (The Case for Georg Lukács, p. 164)

112 Lukács: Die Eigenart I, p. 489, cf. p. 743.

113 Largier: Zeit der Möglichkeit, p. 24.

114 Cf. the chapter »On the Nature and Form of the Essay. A Letter to Leo Popper« (Lukács: Soul and Form, pp. 16-34; „Ein Brief an Leo Popper«, Die Seele und die Formen, pp. 3-39).

115 Largier: Zeit der Möglichkeit, p. 11. 
of form over content, or vice versa, but the mutual tropical relationship of form and content as constituents of the same dialectic form-content unity. To repeat, it is not only in Die Eigenart, which is here construed as providing synthetic answers to the ethic and aesthetic problems articulated in Soul and Form and The Theory of the Novel, that this dialectical unity of content and form is apparent; it is already assumed in the early work:

All writings represent the world in the symbolic terms of a destiny-relationship; everywhere, the problem of destiny determines the problem of form. This unity, this coexistence is so strong that neither element ever occurs without the other; here again a separation is possible only by way of abstraction. ${ }^{116}$

However, if in Die Eigenart Lukács explored the modalities of fusion and the mutual interaction of contents and forms, in Soul and Form he conducted only their analytical secession. The reason why Soul and Form seemingly privileged forms over contents was dictated by its focus on »the nature and form of the essay « and not, for instance, on the novel in its relation to the epic on the one side and the novella on the other. It is due to the artistic character of the essay that the duty of a critic is not exploring destinies but first and foremost exploring the forms these destinies are coated in: »The critic is one who glimpses destiny in forms: whose most profound experience is the soul-content which forms indirectly and unconsciously conceal within themselves. «117

Besides the interest in the form-oriented métier of a critic, Soul and Form unmistakably contains a conceptual draft of what Lukács later theorized as the `homogeneous medium $\prec$. The moment when the critic discerns contents behind forms, i.e., when in the reception process contents emerge transmitted through forms, was qualified as a reward for the intent activity of the essayist. Two pertinent citations from the "Letter to Leo Popper" testify to this unifying mediation of contents through their forms:

Therefore the separation which I am trying to accomplish here appears, in practice, merely as a shift of emphasis: poetry receives its profile and its form from destiny, and form in poetry appears always only as destiny $[\ldots ..] .{ }^{118}$

116 Lukács: Soul and Form, p. 23 (»Jedes Schreiben stellt die Welt im Symbol einer Schicksalsbeziehung dar; das Problem des Schicksals bestimmt überall das Problem der Form. Diese Einheit, diese Koexistenz ist so stark, daß das eine Element nie ohne das andere auftritt und eine Trennung ist auch hier nur in der Abstraktion möglich.", Die Seele und die Formen, p. 16).

117 Ibid. (»Der Kritiker ist der, der das Schicksalhafte in den Formen erblickt, dessen stärkstes Erlebnis jener Seelengehalt ist, den die Formen indirekt und unbewußt in sich bergen.«, Die Seele und die Formen, p. 17)

118 Ibid. (»Die Scheidung also, die ich hier zu vollziehen versuche, scheint praktisch nur ein Unterschied der Betonung zu sein: die Dichtung erhält vom Schicksal ihr Profil, ihre Form, die Form erscheint dort immer nur als Schicksal [...].«, Die Seele und die Formen, p. 16) 
The critic's moment of destiny, therefore, is that moment at which things become forms the moment when all feelings and experiences on the near or the far side of form receive form, are melted down and condensed into form. It is the mystical moment of union between the outer and the inner, between soul and form. ${ }^{119}$

Although these quotes could never be subsumed under the motto »Das determinierende Prinzip ist der Inhalt «, which along with Karl Marx’ saying "Sie wissen es nicht, aber sie tun es" serves as a conceptual backbone of Die Eigenart des Ästhetischen, they nevertheless already forefeel the substance of Lukács' qualification of content as the determining principle of the aesthetic, captured in the following sequel to Die Eigenart's motto:

Das determinierende Prinzip ist der Inhalt. Die künstlerische Form entsteht als das Mittel, einen gesellschaftlich notwendigen Inhalt so auszudrücken, daß eine - ebenfalls ein gesellschaftliches Bedürfnis bildende - konkrete und allgemeine evokative Wirkung entstehe. ${ }^{120}$

It is against the background of these complementary quotes from Soul and Form and Die Eigenart that I acknowledge Butler's remark on form as not merely an expression but already a condition, sign, and possibility of content. ${ }^{121}$ However, her assertion has to be completed by Göcht's conclusion on the preponderance of the content as displayed in the latter citation. Göcht concludes, »[d] ie Form ist immer nur die Form eines bestimmten Inhalts und kann logisch nicht von ihm getrennt werden «. ${ }^{122}$

Die Eigenart's unique position in Lukács' opus as a whole is based on the following: Its most pertinent synthetic procedure concerns the dialectical relationship of the form-content unity as applying by the same token to ssouls and forms in poetry and to the overall relationship of art and society. Namely, the dialectical form-content unity has multiple valences and regards the formal dimensions of literary and artistic genres to the same extent as the overall sociological and even ontological relationship of art and society. As for the latter dimension, it should be noticed that whereas, on the one hand, specifically aesthetic procedures (theorized by Lukács in terms of the 'homogenous medium $<$ ) guarantee art's social distinctiveness, on the other hand, it cannot be expected that art assumes responsibility for

119 Ibid., p. 24 (»Das Schicksalsmoment des Kritikers ist also jenes, wo die Dinge zu Formen werden; der Augenblick, wenn alle Gefühle und Erlebnisse, die diesseits und jenseits der Form waren, eine Form bekommen, sich zur Form verschmelzen und verdichten. Es ist der mystische Augenblick der Vereinigung des Außen und des Innen, der Seele und der Form. «, Die Seele und die Formen, pp. 17-18).

120 Lukács: Die Eigenart I, p. 412.

121 Butler: Introduction, p. 2.

122 Göcht: Mimesis - Subjektivität - Realismus, p. 230. 
the political liberation or scientific enlightenment of humankind: This is the core of the aforementioned stance against a "metaphysische[] Überspannung der Selbstständigkeit « ${ }^{123}$ of both art, science, and ethics. In the final analysis, the social commitment (sozialer Auftrag) of the aesthetic consists of its anthropological and social-philosophical significance that proves to be as substantial as the politics proper, which, however, does not imply the conclusion that aesthetics may act in place of politics. Besides this homology and the simultaneous unexchangeability of politics and aesthetics, the only opposition that remains constant throughout all of Lukács' works is the one between the `whole man ' and the `man as a whole displays a Hegelian dialectics »of the concrete and the abstract « ${ }^{124}$ and is, as such, tackled from the standpoint of both anthropology and psychology as well as from the standpoint of social theory. The moment in which Lukács' aesthetics of form-content unity emerges as social philosophy is precisely the point where the formal procedures of the 'homogenous medium $`$ obtain their social significance:

Jedes homogene Medium entsteht aus dem Bedürfnis der Menschen, die für sie objektiv gegebene Welt, die zugleich die Welt ihrer Freuden und Leiden, vor allem aber die Welt ihrer Tätigkeit, des Ausbaus ihres eigenen Innenlebens und ihrer Wirklichkeitsbewältigung ist, von einem bestimmten, wesentlichen Gesichtspunkt aus näher und konkreter, intensiver und tiefer, umfassender und detaillierter zu ergreifen, als dies für das Alltagsleben möglich ist $[\ldots] .{ }^{125}$

The quote can be exemplified as follows: The formal, tropical function of the form's relation to its other - the content - is both of an antonymic and of a metonymic kind: Although both sides strive for independency, the form is always in proximity to, in fact dependent on, the content, while the content is in turn in continuous need of a form. Now, if we attest to this formal dimension of the form-content unity, the question arises as to what is the content of this unity of opposites - and this is not in the sense of mundane Inhalt but in terms of its meaning or significance, of Gehalt. ${ }^{126}$ Whereas from the standpoint of Soul and Form this question proved to be unanswerable, even unintelligible, and whereas in The Theory of the Novel its solution already, if only timidly, began to emerge, from Die Eigenart's integrative viewpoint it finally became comprehensible that the specifically aesthetic Gehalt consists of overcoming particularity and duality and thus, as Göcht summarizes it, of »laying ground for the enforcement of 
real this-worldliness «. ${ }^{127}$ In contrast to The Theory of the Novel, where it was merely suggested that the novel could make up for the lost totality, Die Eigenart was explicit about the necessity of social commitment of all art, not only of the novel. Here, Lukács unambiguously argued that to achieve this-worldliness, a reconciliation between the formal and content-related side of artwork was mandatory:

Der Befreiungskampf der Kunst ist also - welthistorisch betrachtet - ein Ringen darum, daß der soziale Auftrag der Gesellschaft an sie jene glückliche Mitte zwischen allgemeiner Bestimmtheit des Gehalts und freier Beweglichkeit in der Formgebung erhalte, durch die erst die Kunst ihre Mission als Selbstbewußtsein der Menschengattung erfüllen kann. ${ }^{128}$

On successful eliciting of this felicitous middle ground ("glückliche Mitte«) depends not only the quality of artwork but also the quest for the specifically aesthetic liberation of humankind.

The aforementioned emancipatory goal can be achieved not by semi-religious or moral sermons, also not by pedagogic aims and methods ${ }^{129}$ but by a specifically aesthetic exchange of an >either-or « for the sas well as`. Die Eigenart des Ästhetischen is abundant with tropes of mediation that overcome the binary logic by instituting a third position, which does not lie in-between but comes thereafter, as a synthesis of >one< and `two same applies to the dialectics of autonomy and engagement or of disinterestedness and >Parteilichkeit.${ }^{130}$ Only by means of a mediation between assumed extremes, which is a mediation prepared and developed by art exclusively, can the transgression from the quotidian, fragmented iwhole man $<$ towards the utterly human >man as a whole take place, can the only real duality - the one of the abstract and the concrete - be played out dia-

127 »Grundlagen der Durchsetzung wirklicher Diesseitigkeit« (Göcht: Mimesis - Subjektivität Realismus, p. 212). Cf. Lukács: Die Eigenart I, p. 21; Lukács: Die Eigenart II, p. 815, 822.

128 Lukács: Die Eigenart II, p. 719.

129 Already The Theory of the Novel entertained a critique of plain literary pedagogy. When speaking of »the danger of a subjectivity which is not exemplary, which has not become a symbol, and which is bound to destroy the epic form ", Lukács mentioned the modem novels of education that endow everything "with the fatal, irrelevant and petty character of the merely private; it remains a mere aspect, making the absence of a totality the more painfully obvious as it constantly claims to create one. The overwhelming majority of modem snovels of education have completely failed to avoid this pitfall.« (Lukács: The Theory of the Novel, p. 137) (»[...] die Gefahr einer nicht vorbildlichen, nicht zum Symbol gewordenen Subjektivität, die die epische Form sprengen muß. [...] Und diese Subjektivität ist unaufhebbarer als die des erzählenden Tones: sie gibt allem Dargestellten - selbst wenn die technische Gestaltung aufs vollendetste objektiviert ist - den fatalen, belanglosen und kleinlichen Charakter des bloß Privaten; es bleibt ein Aspekt, der um so unangenehmer die Totalität vermissen läßt, weil er in jedem Moment mit dem Anspruch eine solche zu gestalten, auftritt. Der weitaus größte Teil der modernen Erziehungsromane ist dieser Gefahr rettungslos verfallen.«, Die Theorie des Romans, pp. 148-149)

130 Cf. above, Lukács: Die Eigenart I, p. 616. 
lectically. Now, for the sake of a shift towards the final section of the article, let me conclude this section with perhaps the most apposite statement for the present problem, as found in the chapter »Homogenes Medium, der ganze Mensch und der >Mensch ganz « «: ${ }^{131}$

\begin{abstract}
Das Tertium datur [...] darf aber keine eklektische »Mitte« sein, sondern soll die dialektische Einheit von Inhalt und Form (bei Beibehalten der Priorität des Inhalts in der Bestimmung der Form als die eines konkreten Inhalts, bei ihrer Anerkennung als unmittelbarer Träger der ästhetischen Evokation etc.) in all ihrer Kompliziertheit festhalten und begrifflich formulieren. Wenn nun in der analysierenden Darlegung dies zuweilen nur auf Umwegen über - methodologisch - gesonderte Inhalt- und Formkomponenten möglich ist, so bedeutet dies nicht die geringste Konzession an die soeben verworfene Eklektik einer hier nicht existierenden »Mitte«, denn in jeder getrennten Betrachtung sind diese dialektischen Verflochtenheiten immanent mitgedacht. ${ }^{132}$
\end{abstract}

\title{
5. Tertium datur
}

The final, hitherto insufficiently explored issue regards the question why Lukács arrived, or was able to arrive, at the synthetic solutions proposed in his late aesthetics. In conclusion, it should be remembered that Lukács' account of art in modernity complies with other influential contributions to this discussion, according to which "works of art, including literary ones, point to a practice from which they abstain: the creation of a just life «. ${ }^{133}$ Yet he also argues that art is by its own means not only capable but even obliged to intervene in the world: »Die Dichtung ist zugleich Entdeckung des Lebenskerns und Kritik des Lebens. «; »Die Kunst ist ihrem Wesen nach stets eigene Gegenkraft solcher Entartungstendenzen, stets das Vorbild für den Aufstand wider deren Einflüsse, das Ideal einer inneren Gesundheit. « ${ }^{134}$ Notwithstanding this acknowledgment of art's critical potential - which actually complies with Theodor W. Adorno's statement - »Even in the most sublimated work of art there is a hidden >it should be otherwise « ${ }^{135}$ - an important disconcerting element in Lukács' appreciation of art in its relation to politics stems from his refusal to adulate accounts of art as the bearer of a "promise of total revolutionary praxis «. ${ }^{136}$ Such accounts, however, seemingly

131 Ibid., pp. 606-635; cf. also above, note 67.

132 Ibid., p. 613.

133 Bernstein: The Philosophy of the Novel, p. 228.

134 Lukács: Die Eigenart I, p. 740, p. 743. Cf. also the aforementioned imperative of the >ought 'Sollen< (ibid., pp. 481-482).

135 Adorno: Commitment, p. 194 (»Noch im sublimiertesten Kunstwerk birgt sich ein $\gg$ Es soll anders sein «.", Engagement, p. 429).

136 Roberts: Revolutionary Time and the Avant-garde, p. 61, emphasis J. R. 
revolutionary, are indeed an asset of liberal art politics that simultaneously grant literature its revolutionary ambitions and deny it the power to turn these into practice. The claim of art's »radical passivity «, ${ }^{137}$ namely that in modernity art came to represent a mere placeholder for absent politics, "a stand-in for an absent politics «, ${ }^{138}$ is valid under the condition that modernity be equated with liberalism, both as philosophy and as political economy. This is precisely what Adorno implicitly confesses to when he submits, »[t]his is not a time for political art, but politics has migrated into autonomous art, and nowhere more so than where it seems to be politically dead $\lll .{ }^{139}$ For this reason, Bernstein is right in claiming that to comprehend modern art presupposes grasping the kind of politics that is responsible for the withdrawal of politics from art. He makes a straightforward claim that »[w]ithout a genealogy of liberalism, a genealogy that would give historical substance to the fabled suppression of the political [...], politics bereaved remains an abstraction «. ${ }^{140}$ The origin of Lukács' aesthetics after his Marxist turn is exactly as summarized by Bernstein: without a genealogy and critique of liberalism, which assigns art to its own autonomous and socially detached sphere, the social inability of art remains camouflaged and unrecognized. Furthermore, Bernstein claims that »the >we that would sustain political judgement and praxis has disappeared from direct view « and has literally "gone underground «; as a result, it "appears only through the theoretical tracing of the fate that has rendered us strangers to one another «. ${ }^{141}$ This is another pertinent point put forward by Lukács himself, namely that the social commitment of art ought to consist first and foremost of a critique of the isolation and atomization of individuals who in modernity become unable to elevate themselves on levels higher than their own particular, private interests. ${ }^{142}$ Finally, being unable to act in place of a lost or failed revolution, or to instigate a new one, art can, however - and this is where the >late`Lukács joins in with the `mature` one - assist political revolutions or act under their auspices. Again, this is granted under the condition that art acts as art, that is, by procedures that embody the sspecificity of the aesthetic

137 Wall: Radical Passivity.

138 Bernstein: The Fate of Art, p. 269.

139 Adorno: Commitment, p. 194 (»An der Zeit sind nicht die politischen Kunstwerke, aber in die autonomen ist die Politik eingewandert, und dort am weitesten, wo sie politisch tot sich stellen [...].«, Engagement, p. 430).

140 Bernstein: The Fate of Art, p. 268.

141 Ibid., p. 273.

142 For an early note on this atomization, cf. Lukács: Soul and Form, p. 106 (Die Seele und die Formen, pp. 188-189). 
When Lukács in the 1920s and 1930s classified art and literature as supporters and conveyors of organized revolutionary politics, this was a practical implementation of his analytical insight that any intervention into reality from the exclusive "standpoint of art ${ }^{143}$ was doomed to miscarriage. Therefore, rather than reading the texts from his >mature $<$ phase as programmatic scripts of authoritarian, let alone totalitarian cultural politics, ${ }^{144}$ one should recognize, first, Lukács' stance on the homologous relationship between art and revolution, and second, his insistence that it is vital for art and revolution to operate by distinctively different means and to follow their system-specific duties. Thus, the emancipation of humankind is accomplished by a two-level operation: by political (collective) revolution and simultaneously by the aesthetic creation of the >man as a whole . To confuse one with the other would mean failing both revolution and art. Obviously, although it is agreed that aesthetics was often »the form in which he talked politics «, ${ }^{145}$ Lukács' understanding of the relationship between art and politics was of a conspicuously different tropical character than the related reflections that similarly drew on art's modern right to its own autonomy and specificity. The essential difference between Lukács' socialist aesthetics and the theoretizations of "art under capitalism « ${ }^{146}$ consists of their diverging relationship towards politics: For Lukács, aesthetics serves not as a placeholder for politics but as its companion; it does not gesture towards a just world by means of a rhetorical stance of pars pro toto but acknowledges and even assists politics in its struggle for the liberation of humankind. Yet what applies to the individual subject applies to the same extent to the aesthetic: »on no account must [it] ever become a mere instrument ${ }^{147}$

\section{References}

Adorno, Theodor W.: Commitment. In: Ernst Bloch et al.: Aesthetics and Politics [1977]. Trans. Rodney Livingstone. London: Verso 1980, pp. 177-195 (Engagement. In: Gesammelte Schriften. Vol. 11: Noten zur Literatur. Frankfurt/M.: Suhrkamp 1974, pp. 409-430).

143 Ibid., p. 99 (»Standpunkt der Kunst«, Die Seele und die Formen, p. 175).

144 Göcht (Mimesis - Subjektivität - Realismus, p. 199) refers to articles by Henning (Katharsis der Moderne) and Fohrmann (Über analoge und diskrete Kommunikation). For ‘totalitarian interpretative frameworks in the post-socialist era, cf. Bronner: Lukács and the Dialectic, p. 13.

145 Bronner: Lukács and the Dialectic, p. 25.

146 Roberts: Revolutionary Time and the Avant-garde, p. 224.

147 Löwy: Georg Lukács, p. 127. 
Adorno, Theodor W.: Erpreßte Versöhnung. In: Gesammelte Schriften. Vol. 11: Noten zur Literatur. Frankfurt/M.: Suhrkamp 1974, pp. 251-280 (Reconciliation under Duress. In: Ernst Bloch et al.: Aesthetics and Politics [1977]. Trans. Rodney Livingstone. London: Verso 1980, pp. 151-176).

Anderson, Perry: Considerations on Western Marxism [1976]. London, New York: Verso 1989. Arato, Andrew; Breines, Paul: Young Lukács and the Origins of Western Marxism. New York: The Seabury Press 1979.

Bernstein, Jay M.: The Philosophy of the Novel. Lukács, Marxism and the Dialectics of Form. Minneapolis: University of Minnesota Press 1984.

Bernstein, Jay M.: The Fate of Art: Aesthetic Alienation from Kant to Derrida and Adorno. Cambridge: Polity Press 1993.

Bivens, Hunter: Epic and Exile: Novels of the German Popular Front, 1933-1945. Evanston, IL: Northwestern UP 2015.

Bronner, Stephen Eric: Lukács and the Dialectic: Contributions to a Theory of Practice. In: Georg Lukács Reconsidered. Critical Essays in Politics, Philosophy and Aesthetics. Ed. Michael J. Thompson. London, New York: Continuum 2011, pp. 13-32.

Butler, Judith: Introduction. In: Georg Lukács: Soul and Form. 1910/1911. Eds. John T. Sanders, Katie Terezakis. New York: Columbia UP 2010, pp. 1-15.

Crow, Dennis: Form and the Unification of Aesthetics and Ethics in Lukács' Soul and Forms. »New German Critique« 15 (1978), pp. 159-177.

Fohrmann, Jürgen: Über analoge und diskrete Kommunikation. Georg Lukács, der Erste Weltkrieg und die Theorie des Romans. In: Die Souveränität der Literatur. Zum Totalitären der Klassischen Moderne 1900-1930. Eds. Uwe Hebekus, Ingo Stöckmann. München, Paderborn: Fink 2008, pp. 111-126.

Göcht, Daniel: Mimesis - Subjektivität - Realismus. Eine kritisch-systematische Rekonstruktion der materialistischen Theorie der Kunst in Georg Lukács' Die Eigenart des Ästhetischen. Bielefeld: Aisthesis Verlag 2017.

Hartley, Daniel: Politics of Style. Towards a Marxist Poetics. Leiden, Boston: Brill 2016.

Henning, Anke: Katharsis der Moderne. In: Grenzen der Katharsis in den modernen Künsten: Transformationen des aristotelischen Modells seit Bernays, Nietzsche und Freud. Eds. Martin Vöhler, Dirck Linck. Berlin et al.: De Gruyter 2009, pp. 139-173.

Jameson, Fredric: The Case for Georg Lukács. In: Jameson: Marxism and Form: Twentieth-Century Dialectical Theories of Literature [1971]. Princeton, New Jersey: Princeton UP 1974, pp. 160-205.

Jameson, Fredric: Reflections in Conclusion. In: Ernst Bloch et al.: Aesthetics and Politics [1977]. Trans. Rodney Livingstone. London: Verso 1980, pp. 196-213.

Jay, Martin: Marxism and Totality. The Adventures of a Concept from Lukács to Habermas. Berkeley, Los Angeles: University of California Press 1984.

Johnson, Pauline: Die Eigenart des Aesthetischen (The Specificity of the Aesthetic). In: P. Johnson: Marxist Aesthetics. The Foundations within Everyday Life for an Emancipated Consciousness. London et al.: Routledge, Kegan Paul 1984, pp. 34-46.

Largier, Niklaus: Zeit der Möglichkeit. Robert Musil, Georg Lukács und die Kunst des Essays. Hannover: Wehrhahn 2016.

Löwy, Michael: Georg Lukács: From Romanticism to Bolshevism. London: NLB 1979.

Lukács, Georg: Die Eigenart des Ästhetischen [1963]. 2 vols. Berlin, Weimar: Aufbau 1987.

Lukács, Georg: Erzählen oder Beschreiben? [1936]. In: Georg Lukács Werke. Vol. 4. Probleme des Realismus I. Essays über Realismus. Neuwied, Berlin: Luchterhand 1971, pp. 197-242. 
Lukács, Georg: Es geht um den Realismus [1938]. In: Georg Lukács Werke. Vol. 4. Probleme des Realismus I. Essays über Realismus. Neuwied, Berlin: Luchterhand 1971, pp. 313-343 (Realism in the Balance. In: Ernst Bloch et al.: Aesthetics and Politics [1977]. Trans. Rodney Livingstone. London: Verso 1980, pp. 28-59).

Lukács, Georg: Gelebtes Denken. Eine Autobiographie im Dialog. Trans. Hans-Henning Paetzke. Frankfurt/M.: Suhrkamp 1981.

Lukács, Georg: Die Seele und die Formen. Essays. Berlin: Egon Fleischel \& co. 1911 (Soul and Form [1910/1911]. Eds. John T. Sanders, Katie Terezakis. New York: Columbia UP 2010).

Lukács, Georg: Tailism and the Dialectic. In: Lukács: A Defence of History and Class Consciousness. Tailism and the Dialectic. Trans. Esther Leslie. London, New York: Verso 2000, pp. 45-149.

Lukács, Georg: Tendenz oder Parteilichkeit? »Die Linkskurve« 4.6 (1932), pp. 13-21.

Lukács, Georg: Die Theorie des Romans. Ein geschichtsphilosophischer Versuch über die Formen der großen Epik. Berlin: Paul Cassirer 1920 (The Theory of the Novel. A historico-philosophical essay on the forms of great epic literature [1915/1920]. Trans. Anna Bostock. Cambridge, MA: The MIT Press 1971).

Lukács, Georg: The Young Hegel. Studies in the Relations between Dialectics and Economics. Trans. Rodney Livingstone. London: Merlin Press 1975.

Perica, Ivana: Aisthesis verorten - Rancières ästhetische Evolution oder: literarische Szenen eines politischen Konflikts. In: Jacques Rancière und die Literatur. Eds. Erik M. Vogt, Michael Manfé. Wien, Berlin: Turia + Kant 2020, pp. 40-63.

Rebentisch, Juliane: Realism Today. Art, Politics, and the Critique of Representation. In: Thinking - Resisting - Reading the Political. Eds. Anneka Esch-van Kan, Philipp Schulte, Stephan Packard. Zurich: Diaphanes 2013, pp. 245-261.

Rees, John: Introduction. In: Georg Lukács: A Defence of History and Class Consciousness. Tailism and the Dialectic. Trans. Esther Leslie. London, New York: Verso 2000, pp. 1-38.

Roberts, John: Revolutionary Time and the Avant-garde. London: Verso 2015.

Rockhill, Gabriel: Radical History \& the Politics of Art. New York: Columbia UP 2014.

Sonderegger, Ruth: Neue Formen der Organisierung. Kunst und Politik nach Jacques Rancière. In: Blindheit und Hellsichtigkeit. Künstlerkritik an Politik und Gesellschaft der Gegenwart. Ed. Cornelia Klinger. Berlin: De Gruyter 2014, pp. 285-302.

Ventura, Holger Kube: Gegen Kunsttheorie. Zur Frage nach dem politischen Charakter von Kunst. In: Politik der Kunst: Über Möglichkeiten, das Ästhetische politisch zu denken. Eds. Leonhard Emmerling, Ines Kleesattel. Bielefeld: Transcript 2016, pp. 199-210.

Wall, Thomas Carl: Radical Passivity: Lévinas, Blanchot, and Agamben. New York: Suny Press 1999. 